(С) Верітов О. І., $2020 \mathrm{p}$.

http://orcid.org/0000-0002-3793-3010

https://doi.org/10.34142/23128046.2020.49.03

O. I. Bepimoв

\title{
ФОРМУВАННЯ МАРКЕТИНГОВИХ КОМПЕТЕНЦІЙ БАКАЛАВРІВ ІЗ ФІЗИЧНОї КУЛЬТУРИ І СПОРТУ
}

У статті репрезентовано авторське бачення щзодо логіки викладення навчального матеріалу дисиипліни «Маркетинг фізичної культури і спорту», визначено ії місие у структурно-логічній схемі навчального процесу та методи проведення навчальних занять і самостійної роботи студентів. Для досягнення поставленої мети було використано абстрактно-логічний та системноструктурний методи дослідження. Зазначено, що засвоєння здобувачами вищої освіти основних теоретичних і практичних положень дисиипліни доречно на другому курсі (четвертий семестр). Головним завданням дисципліни $\epsilon$ формування у майбутніх бакалаврів фізичної культури і спорту установки на задоволення потреб споживачів при здійсненні підприємницької діяльності. Структура дисципліни складається з восьми тем, щзо представлені в чотирьох змістовних модулях, які об'єднано у два структурні модулі. Формами й методами аудиторної роботи визначено: традиційні лекції, лекиії-презентації, метод мозкового штурму, метод проблемного навчання, круглий стіл у форматі дискусії між студентами, виконання навчальних завдань із заздалегідь визначеним результатом, метод інформування, «фантазування», метод зразків, метод фокальних об'єктів, методи інтерактивнокомунікативного навчання, дискусія із запрошенням підприємиів-практиків щуодо обговорення проблемних питань здійснення підприємницької діяльності. У межах теми «Маркетингові стратегї̈» передбачено проведення індивідуального заняття, метою якого є допомога студентам у вирішенні питань щодо планування підприємницької діяльності. При цььому запропоновано використовувати метод евристичної бесіди. Наведена логіка проведення аудиторної і забезпечення виконання самостійної роботи студентів під час вивчення дисиипліни створює умови для формування: навичок визначення й задоволення потреб і інтересів споживачів; навичок здійснення аналізу ринку послуг професійних тренерів, агентів, менеджерів та інших фахівців; вміння встановлювати конкурентоспроможну ціну на спортивно-оздоровчі послуги; розуміння сутності створення ци просування власного бренду; здатності обирати й проводити найбільш ефективні PR-заходи; навичок аналізу зовнішніх загроз і можливостей, а також внутрішніх сильних і слабких сторін власного бізнесу; навичок розроблення маркетингового плану для власного стартапу; упевненості студентів у власному підприємницькому потениіалі. 
Ключові слова: змістовне наповнення дисиипліни, методи навчання, підприємницька діяльність, підприємницька культура, аналіз ринку, PR-заходи, SWOT-аналіз, підприємницький потенціал.

Veritov O. I. Formation of marketing competencies of bachelors in physical culture and sport. The article presents the author's vision of the logic of teaching the subject "Marketing of Physical Culture and Sports", defines its place in the structural and logical scheme of the educational process and methods of teaching and independent work of students. To achieve this goal, abstract-logical and systemstructural research methods were used. It is stated that the acquiring of theoretical and practical concepts of the discipline by undergraduate students is appropriate in the second year (fourth semester). The main task of the discipline is the formation of future bachelors of physical culture and sports attitudes to meet the needs of consumers while doing business. The structure of the discipline consists of eight topics, which consist of four content modules, which are combined into two structural modules. Forms and methods of classroom work are defined as traditional lectures, lectures-presentations, method of brainstorming, method of problem-based learning, round table in the format of discussion between students, learning tasks with predetermined results, method of informing, "fantasizing", method of samples, Theory of Inventive Problem Solving (TIPS), method of focal objects, methods of interactivecommunicative learning, discussion with the invitation of entrepreneurs-practitioners to discuss problematic issues of entrepreneurial activity. Within the framework of the topic "Marketing Strategies" there is an individual lesson, the purpose of which is to help students in solving issues related to business planningwhich uses the method of heuristic conversation. The suggested logic of carrying out of a classroom and maintenance of performance of independent work of students during studying of discipline creates conditions for formation of skills to define and satisfyneeds and interests of consumers; skills of market analysis of services of professional coaches, agents, managers and other specialists; ability to set a competitive price for sports and health services; understanding the essence of creating and promoting your own brand; ability to choose and conduct the most effective PR activities; skills of analysis of external threats and opportunities, as well as internal strengths and weaknesses of their own business; skills to develop a marketing plan for your own startup; formation of students' confidence in their own entrepreneurial potential.

Keywords: content of the discipline, methods of conducting classes, entrepreneurial activity, entrepreneurial culture, market analysis, PR-events, SWOTanalysis, entrepreneurial potential.

Вступ. Щорічно закладами вищої освіти (ЗВО) України випускається приблизно 6000 фахівців з фізичної культури і спорту (ФКС), більшість із яких у якості професійної кар'єри обирають викладацьку діяльність. Однак, на початок 2019 року показник навантаження зареєстрованих безробітних на одну вакансію у сфері ФКС дорівнював 5,8 осіб, у той час як загальний 
середньорічний показник по Україні становив 3,6 осіб (Kilkist zareiestrovanykh bezrobitnykh ta kilkist vakansii u 2019 rotsi (za danymy derzhavnoi sluzhby zainiatosti), 2020). Таку ситуацію спроможе виправити самозайнятість фахівців, тобто самостійна підприємницька діяльність. Саме тому підвищення якості підприємницької освіти майбутніх бакалаврів із фізичної культури і спорту $є$ актуальним завданням. Серед загальних вимог щодо економічних знань та вмінь фахівця 3 фізичної культури і спорту під час здійснення господарської діяльності, не зважаючи на вид підприємницької діяльності та організаційноправову форму бізнесу, а також враховуючи реалії ринкової економіки, слід зазначити навички володіння маркетинговими технологіями.

Висвітлення проблемних питань маркетингу в спортивній сфері $\epsilon$ напрямом наукових пошуків багатьох вітчизняних авторів. Серед таких напрямів можна зазначити: визначення основних аспектів підготовки маркетологів у сфері спортивного бізнесу (Samodai, 2013), дослідження сучасних особливостей маркетингової діяльності у сфері спорту (Tanklevska \& Vybranskyi, 2019), визначення особливостей основних інструментів комплексу маркетингу підприємств сфери фізичної культури і спорту (Potapiuk, 2011), актуалізація індивідуально-орієнтованого і антропоцентричного маркетингових підходів до фізичного виховання (Razumovskyi, 2013), з'ясування структурних компонентів готовності майбутніх фахівців фізичного виховання та спорту до маркетингової діяльності (Tyshchenko, 2010). Однак, на нашу думку, недостатньо приділено уваги питанням викладання дисципліни «Маркетинг фізичної культури і спорту», а саме їі місця у структурно-логічній схемі навчального процесу та змістовного наповнення.

Мета та завдання. Метою статті є презентація авторського бачення щодо логіки викладення навчального матеріалу дисципліни «Маркетинг фізичної культури і спорту», визначення іiі місця у структурно-логічній схемі навчального процесу та методів проведення навчальних занять і самостійної роботи студентів. Досягнення зазначеної мети обумовлено виконанням таких завдань:

- визначити обсяг, структуру та змістовне наповнення навчальної дисципліни, що забезпечує формування у майбутніх бакалаврів фізичної культури і спорту маркетингових компетенцій;

- запропонувати форми і методи організації навчального процесу.

Методи дослідження. Для досягнення поставленої мети було використано абстрактно-логічний (для виявлення логічних взаємозв'язків між змістовними елементами навчальної дисципліни, а також для теоретичного узагальнення i формулювання висновків) та системно-структурний (для вивчення об'єкту дослідження (маркетингових компетенцій) як цілісної структури та вивчення окремих його складників).

Результати. Відповідно до авторської концепції формування підприємницької культури майбутніх бакалаврів фізичної культури і спорту, навчальний план спеціальності повинен включати такі вибірокві дисципліни, 
як: «Інформаційні технології у фізичній культурі і спорті» (другий семестр), «Менеджмент у фізичній культурі і спорті» (третій семестр), «Маркетинг фізичної культури і спорту» (четвертий семестр), «Підприємництво у фізичній культурі і спорті» (п’ятий семестр), «Інноваційні технології спортивного тренування та фізичної культури» (шостий семестр).

Отже, засвоєння здобувачами вищої освіти основних теоретичних i практичних положень дисципліни «Маркетинг фізичної культурі і спорту» доречно на другому курсі. Серед маркетингових know-how, якими повинен володіти спортсмен-професіонал для успішного ведення власної справи, можна зазначити: навички здійснення аналізу ринку послуг професійних тренерів, агентів, менеджерів та інших фахівців; вміння встановлювати конкурентоспроможну ціну на власні послуги; розуміння сутності створення й просування власного бренду; здатність обирати й проводити найбільш ефективні PR-заходи.

Завдання щодо формування зазначених знань і вмінь, на наш погляд, вирішує розроблене нами змістовне наповнення навчальної дисципліни «Маркетинг фізичної культури і спорту», структура якої (витяг 3 робочої навчальної програми) представлена у табл. 1.

Таблиия 1

\section{Структура навчальної дисципліни «Маркетинг фізичної культури і} спорту» (витяг з робочої навчальної програми)

\begin{tabular}{|c|c|c|c|c|c|c|}
\hline \multirow[b]{3}{*}{ Назви змістовних модулів і тем } & \multicolumn{6}{|c|}{ Кількість годин } \\
\hline & \multirow[b]{2}{*}{$\begin{array}{l}0 \\
\stackrel{0}{0} \\
\stackrel{0}{0}\end{array}$} & \multicolumn{5}{|c|}{ зокрема } \\
\hline & & 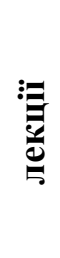 & 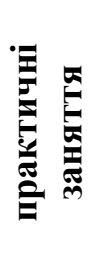 & 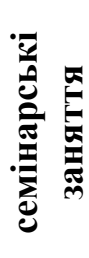 & 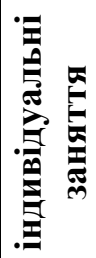 & 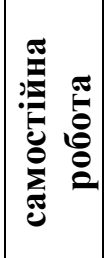 \\
\hline \multicolumn{7}{|c|}{ Струуктурний модуль 1} \\
\hline \multicolumn{7}{|c|}{$\begin{array}{l}\text { Змістовий модуль 1. Загальні положення та особливості маркетингу фізичної культури і } \\
\text { спорту }\end{array}$} \\
\hline $\begin{array}{l}\text { Тема 1. Загальна характеристика маркетингу фізичної } \\
\text { культури і спорту }\end{array}$ & 16 & 4 & 2 & - & - & 10 \\
\hline $\begin{array}{l}\text { Тема 2. Методологія Customer development як основа } \\
\text { сучасного бізнесу }\end{array}$ & 14 & 2 & 2 & 2 & - & 8 \\
\hline Разом за змістовим модулем 1 & 30 & 6 & 4 & 2 & - & 18 \\
\hline \multicolumn{7}{|c|}{ Змістовий модуль 2. Підготовка послуг галузі фізичної культури і спорту до виходу на ринок } \\
\hline Тема 3. Маркетингові дослідження & 16 & 2 & 2 & - & - & 12 \\
\hline $\begin{array}{l}\text { Тема 4. Ціноутворення у галузі фізичної культури і } \\
\text { спорту }\end{array}$ & 14 & 2 & 2 & - & - & 10 \\
\hline Разом за змістовим модулем 2 & 30 & 4 & 4 & - & - & 22 \\
\hline Усього годин & 60 & $\mathbf{1 0}$ & 8 & 2 & - & 40 \\
\hline \multicolumn{7}{|c|}{ Структурний модуль 2} \\
\hline Змістовий модуль 3. Просування послуг галузі фізичнс & & 110 & оту 1 & ин & & \\
\hline $\begin{array}{l}\text { Тема 5. Образ і товарні константи послуг галузі } \\
\text { фізичної культури і спорту }\end{array}$ & 16 & 2 & 2 & 2 & - & 10 \\
\hline
\end{tabular}




\begin{tabular}{|l|c|c|c|c|c|c|}
\hline Тема 6. Основи РRО-МIX. Реклама та РR & 14 & 2 & 2 & - & - & 10 \\
\hline Разом за змістовим модулем 3 & 30 & 4 & 4 & 2 & - & 20 \\
\hline Змістовий модуль 4. Перспективне маркетингове планування \\
\hline Тема 7. SWОТ-аналіз & 16 & 2 & 2 & - & - & 12 \\
\hline Тема 8. Маркетингові стратегії & 14 & 2 & 2 & 2 & 2 & 6 \\
\hline Разом за змістовим модулем 4 & 30 & 4 & 4 & 2 & 2 & 18 \\
\hline Усього годин & $\mathbf{6 0}$ & $\mathbf{8}$ & $\mathbf{8}$ & $\mathbf{4}$ & $\mathbf{2}$ & $\mathbf{3 8}$ \\
\hline Разом & $\mathbf{1 2 0}$ & $\mathbf{1 8}$ & $\mathbf{1 6}$ & $\mathbf{6}$ & $\mathbf{2}$ & $\mathbf{7 8}$ \\
\hline
\end{tabular}

Головними завданням цієї дисципліни $є$ формування у майбутніх бакалаврів фізичної культури і спорту установки на задоволення потреб споживачів при здійсненні підприємницької діяльності.

Перша тема «Загальна характеристика маркетингу фізичної культури i спорту» передбачає проведення лекцій (4 год.), практичного заняття (2 год.), а також організацію самостійної роботи (10 год.). Лекції мають традиційний характер з елементами лекції-презентації (наочне представлення плану лекції та схеми знань). Зміст першої лекції містить такі питання: історія виникнення маркетингу; визначення маркетингу оздоровчих послуг; функції маркетингу реабілітаційних послуг; цілі маркетингу спортивно-оздоровчих послуг; основні категорії маркетингу спортивно-оздоровчих послуг.

Завданням другої лекції $є$ висвітлення сутності комплексу маркетингу в сфері фізкультурно-оздоровчих послуг (4P) та особливостей його реалізації. Специфікою цієї частини освітнього процесу є експрес-опитування студентів на початку другої лекції з метою актуалізації знань.

Метою практичного заняття $є$ уточнення розуміння маркетингу через аналіз існуючих визначень (дидактичний матеріал), з наступним критичним есе 3 приводу існуючих визначень маркетингу. Для цього можна використовувати метод мозкового штурму, результатом якого буде обгрунтування (групової) дефініції поняття. Практичне заняття доцільно розпочати з індивідуальної роботи - написання критичного есе, а завершити «мозковим штурмом» розробленням нової дефініції маркетингу, що дає змогу залучили до спілкування усіх здобувачів освіти.

Наступна тема «Методологія Customer development як основа сучасного бізнесу» інтегрує лекцію (2 год.), практичне заняття (2 год.), семінар (2 год.) та самостійну роботу (8 год.). Проведення лекції у традиційній формі дозволяє надати інформацію стосовно визначення й задоволення потреб і інтересів споживачів як мети підприємницької діяльності, сутності клієнтоорієнтованого підходу до створення бізнесу Customer development та його алгоритму. В основу лекції було покладено роботи С. Бланка (Blank, 2009; Blank, 2017; Blank, 2020).

Практичне заняття має за мету опрацювання студентами лекційного матеріалу через усне фронтальне опитування. Після чого студентам пропонується скласти план розвитку свого бізнесу за алгоритмом Customer development, при цьому матеріал лекції не використовувати. Отже, на цьому 
занятті застосовуються метод фронтального опитування та метод проблемного навчання, що надає навчальному процесу певної динаміки.

Мета семінару полягає в актуалізації здатності студентів до відстоювання своєї позиції, сприяння набуттю ними професійної суб'єктності. Тема семінару: «Краса тіла як мета споживання. Гендерні особливості споживання фізкультурно-оздоровчих послуг». Метод проведення семінару - круглий стіл у форматі дискусії між студентами. При цьому спілкування організовує викладач, який вступним словом позначає правила ведення дискусії, а також основи методу ПРЕС. Вступне слово мало також мотивуюче значення. Не зважаючи на достатньо високу емоційність, студенти із задоволенням беруть участь в обговоренні актуальної для них теми.

Тема «Маркетингові дослідження» передбачає проведення лекції (2 год.), практичного заняття (2 год.) та самостійну роботу студентів (12 год.). Лекцію можна проводити у традиційній формі з елементами інтерактивності (викладач відповідає на запитання студентів по ходу лекції). Змістовне наповнення лекційного матеріалу стосується визначення поняття «маркетингове дослідження», основних його принципів, видів, етапів, цілей та програми.

Практичне заняття в межах цієї теми присвячено основам роботи 3 програмою «Statistica 10» як найбільш доступним сучасним інструментом для оброблення даних маркетингового дослідження. Студентам після роз'яснення основ роботи 3 програмою, видаються навчальні завдання для оброблення у модулях програми «Багатомірні відгуки та дихотомії», «Непараметрична статистика», «Основи статистики». Студентам необхідно створити таблицю даних у програмі «Statistica 10», заповнити цю таблицю даними 3 отриманої картки та провести обрахунок і аналіз цих даних із наступною інтерпретацією. На цьому занятті використовується метод виконання навчальних завдань із регламентованим результатом.

Наступна тема «Ціноутворення у галузі фізичної культури і спорту» також передбачає проведення лекції (2 год.), практичного заняття (2 год.) та самостійної роботи (10 год.). Лекцію доцільно проводити у традиційній формі 3 елементами лекції-презентації задля візуалізації змісту понять через ментальні карти та концептуальні схеми, що значно спрощує сприйняття студентами матеріалу, який стосується: цілей цінової політики організації; методів ціноутворення; процесу встановлення ціни, знижки й націнки на послугу; відповідності ціни і якості послуг; особливостей ціноутворення ринку спортивно-оздоровчих послуг.

Практичне заняття в межах цієї теми передбачає набуття студентами навичок розрахунку ціни на фізкультурно-спортивну послугу. Кожен студент отримує картку з вихідними даними (послуги плавання, фітнесу, out door programs та ін.). Після чого проводить розрахунок вартості річного, піврічного, місячного та разового абонементів. Студенти також обгрунтовують можливі націнки та знижки. При цьому використовується метод виконання навчальних занять із заздалегідь регламентованим результатом. 
Наступна тема «Образ і товарні константи послуг галузі фізичної культури і спорту» інтегрує лекцію (2 год.), практичне заняття (2 год.), семінар (2 год.) та самостійну роботу (10 год.). Проведення лекційного заняття у форматі лекції-презентації дозволяє не тільки висвітлити теоретичний матеріал, що стосується знакових систем як інструментів формування образів; фірмового образу і стилю; сутності товарного знаку, торговельної марки, фірмовим константам, бренду і брендінгу, а й навести чисельні приклади фірмового стилю товарів та послуг галузі «Фізична культура і спорт».

Метою практичного заняття у межах цієї теми є знайомство студентів із кращими зразками фірмового стилю організацій та продуктів фізкультурноспортивної галузі, що виступало в якості «ініціатору» їх творчої активності. Після цього студенти отримали завдання щодо формулювання власної концепції фірмового стилю. Тобто на занятті в якості методів організації навчання доцільно застосовувати метод інформування та «фантазування», метод зразків, ТРИЗ, метод фокальних об'єктів.

Семінарське заняття передбачає презентацію та колективне обговорення студентами власних розробок фірмового стилю. По суті, на семінарі використовується метод «Презентація та захист результатів самостійної роботи», який належить до методів інтерактивного-комунікативного навчання.

Засвоєння навчального матеріалу теми «Основи PRO-MIX. Реклама та PR» передбачає проведення лекції у традиційному форматі (2 год.), практичного заняття (2 год.) та організацію самостійної роботи (10 год.). Змістовними елементами лекційного матеріалу є: складові Pro-mix; поняття реклами, ії плюси і мінуси; критерії класифікації реклами; способи поширення реклами; планування рекламної компанії; визначення пропаганди та іiї основних напрямів; засоби й прийоми пропаганди; основні риси PR; схожість i відмінності PR і реклами; пабліситі як один із засобів PR.

Практичне заняття має за мету закріплення теоретичних знань завдяки розробленню студентами рекламних звернень у відповідності до матриці BCG. Основним методом організації освітнього процесу при цьому $\epsilon$ метод виконання навчальних завдань із регламентованим результатом. На занятті студенти лише розпочинають виконання завдання, а більша його частина виконується у формі самостійної роботи.

Вивчення теми «SWOT-аналіз» передбачає проведення у традиційному форматі лекції (2 год.), практичного заняття (2 год.) та самостійну роботу студентів (12 год.). Зміст лекції складають питання: сутність SWOT-аналізу; методика проведення SWOT-аналізу; особливості SWOT-аналізу в галузі фізичної культури і спорту.

На практичному занятті студентам пропонується здійснити SWOT-аналіз для уявного стартапу. Результат виконання завдання має прикладне значення, оскільки може бути реалізований студентами при виборі напряму підприємницької діяльності.

Тема «Маркетингові стратегії» передбачає ознайомлення студентів із 
базовими стратегіями розвитку підприємства, маркетинговими стратегіями за типологією Дж. П. Грайма, прикладами успішного маркетингового планування в галузі та структурою маркетингового плану організації. Лекцію (2 год.) доцільно проводити у традиційному форматі з використанням мультимедійної наочності. Зокрема, наведення типології стратегій маркетингового планування у вигляді дерева понять, сприяє кращому засвоєнню студентами теоретичного матеріалу.

На практичному занятті (2 год.) студентам пропонується розробити маркетинговий план для власного стартапу, що повинен містити його короткий опис, визначення концепції ціноутворення, шляхів виведення продукту на ринок, цільової аудиторії та інших параметрів. На цьому занятті застосовується метод проблемного навчання, сутність якого полягає в теоретичному вирішенні поставленої проблеми. Часові межі практичного заняття не дозволяють виконати поставлене завдання в повному обсязі. Тому його завершення передбачає самостійну роботу студентів.

Програма дисципліни «Маркетинг фізичної культури i спорту» передбачає значний обсяг самостійної роботи, змістовне наповнення якої узагальнено у табл. 2.

Таблиия 2

\section{Самостійна та індивідуальна робота до дисципліни «Маркетинг фізичної культури і спорту» (витяг з силабусу)}

\begin{tabular}{|c|c|c|c|c|}
\hline Зміст самостійної роботи & Результат & Контрольні заходи & Год. & $\begin{array}{l}\text { Конс. } \\
\text { (год.) }\end{array}$ \\
\hline \multicolumn{5}{|c|}{ Тема 1. Загальна характеристика маркетингу фізичної культури і спорту } \\
\hline $\begin{array}{l}\text { Розроблення та } \\
\text { обгрунтування власного } \\
\text { визначення маркетингу } \\
\text { фізкультурно-спортивної } \\
\text { галузі }\end{array}$ & $\begin{array}{l}\text { Власне визначення } \\
\text { маркетингу } 3 \\
\text { невеликим (до } 1 \text { стор. } \\
\text { А4 обгрунтуванням) }\end{array}$ & $\begin{array}{c}\text { Презентація } \\
\text { визначення, через } \\
\text { модуль «Завдання» } \\
\text { Moodle }\end{array}$ & 10 & - \\
\hline \multicolumn{5}{|c|}{ Тема 2. Методологія Customer development як основа сучасного бізнесу } \\
\hline $\begin{array}{l}\text { Робота з сайтом Steve } \\
\text { Blank's Website. URL: } \\
\text { https://steveblank.com }\end{array}$ & $\begin{array}{l}\text { Есе з викладенням } \\
\text { думок щодо ідей } \\
\text { С. Бланка }\end{array}$ & $\begin{array}{l}\text { Презентація есе через } \\
\text { модуль «Завдання» } \\
\text { Moodle }\end{array}$ & 8 & 2 \\
\hline \multicolumn{5}{|c|}{ Тема 3. Маркетингові дослідження } \\
\hline $\begin{array}{l}\text { 1. Створення інструменту } \\
\text { маркетингового дослідження } \\
\text { (анкети) для використання } \\
\text { серед здобувачів освіти } \\
\text { 2. Проведення анкетування } \\
\text { серед студентів групи } \\
\text { 3. Оброблення результатів } \\
\text { дослідження }\end{array}$ & $\begin{array}{l}\text { Звіт про проведене } \\
\text { дослідження }\end{array}$ & $\begin{array}{l}\text { Презентація звіту } \\
\text { через модуль } \\
\text { «Завдання» Moodle }\end{array}$ & 12 & 2 \\
\hline \multicolumn{5}{|c|}{ Тема 4. Ціноутворення у галузі фізичної культури і спорту } \\
\hline $\begin{array}{l}\text { 1. Виконання навчального } \\
\text { завдання з розрахунку ціни } \\
\text { на фізкультурно-спортивну } \\
\text { послугу }\end{array}$ & $\begin{array}{l}\text { Прайс-лист } \\
\text { фізкультурно- } \\
\text { спортивної послуги }\end{array}$ & $\begin{array}{l}\text { Презентація звіту } \\
\text { через модуль } \\
\text { «Завдання» Moodle. } \\
\text { Модульне тестування } \\
\text { через інструмент }\end{array}$ & 10 & 2 \\
\hline
\end{tabular}




\begin{tabular}{|c|c|c|c|c|}
\hline & & «Тест» & & \\
\hline $\begin{array}{l}\text { Розроблення фірмового } \\
\text { стилю фізкультурно- } \\
\text { спортивної організації або } \\
\text { продукту }\end{array}$ & $\begin{array}{l}\text { Фірмовий стиль } \\
\text { фізкультурно- } \\
\text { спортивної організації } \\
\text { або продукту у } \\
\text { вигляді ескізу або } \\
\text { презентації } \\
\text { з коротким текстовим } \\
\text { описанням ідеї }\end{array}$ & $\begin{array}{l}\text { Презентація } \\
\text { фірмового стилю } \\
\text { через модуль } \\
\text { «Завдання» Moodle } \\
\text { або на семінарському } \\
\text { занятті }\end{array}$ & 10 & 2 \\
\hline \multicolumn{5}{|c|}{ Тема 6. Основи PRO-MIX. Реклама та PR } \\
\hline $\begin{array}{l}\text { Розроблення рекламних } \\
\text { звернень у відповідності до } \\
\text { BCG matrix }\end{array}$ & $\begin{array}{l}\text { Чотири рекламних } \\
\text { звернення, створених } \\
\text { для довільно } \\
\text { обраного продукту } \\
\text { галузі } \\
\end{array}$ & $\begin{array}{l}\text { Оцінювання } \\
\text { рекламних звернень } \\
\text { через модуль } \\
\text { «Завдання» Moodle }\end{array}$ & 10 & - \\
\hline \multicolumn{5}{|l|}{ Тема 7. SWOT аналіз } \\
\hline $\begin{array}{l}\text { Проведення SWOT аналізу } \\
\text { для уявленого стартапу }\end{array}$ & $\begin{array}{l}\text { Матриця SWOT } \\
\text { аналізу }\end{array}$ & $\begin{array}{l}\text { Оцінювання матриці } \\
\text { SWOT аналізу через } \\
\text { модуль «Завдання» } \\
\text { Moodle }\end{array}$ & 12 & 2 \\
\hline \multicolumn{5}{|l|}{ Тема 8. Маркетингові стратегії } \\
\hline $\begin{array}{l}\text { Розроблення плану } \\
\text { маркетингу власного } \\
\text { стартапу }\end{array}$ & $\begin{array}{l}\text { План маркетингу } \\
\text { власного стартапу }\end{array}$ & $\begin{array}{l}\text { Оцінювання плану } \\
\text { маркетингу стартапу } \\
\text { через модуль } \\
\text { «Завдання» Moodle. } \\
\text { Модульне тестування } \\
\text { через інструмент } \\
\text { «Тест» Moodle }\end{array}$ & 6 & - \\
\hline \multicolumn{3}{|l|}{ Рaзом } & 78 & $\mathbf{1 0}$ \\
\hline
\end{tabular}

За нашим задумом, під час навчання тренерів-викладачів, самостійна робота студентів має бути спрямована на опрацювання відомостей, отриманих на практичних заняттях. Зокрема, ця робота повинна включати аналіз студентами методичних матеріалів, який поєднується 3 рефлексією власного досвіду використання тих чи інших методів у мінливих педагогічних ситуаціях.

У межах засвоєння навчального матеріалу теми «Маркетингові стратегії» програмою дисципліни також передбачено проведення семінарського заняття (2 год.), метою якого є залучення студентів до обговорення проблемних питань здійснення підприємницької діяльності та формування у них упевненості у власному підприємницькому потенціалі. Семінар доцільно проводити в формі дискусії 3 запрошенням підприємців-практиків. Зміст такого спілкування $\epsilon$ емоційно насиченим, стимулює пізнавальну активність, викликає у студентів особистий інтерес.

Очевидно, що основною вимогою до запрошеного підприємця-практика є високий рівень особистісних i професійних якостей, а також здатність 
ефективно «реалізовувати» ці якості на когнітивному, афективному та поведінковому рівнях. Очікуваним результатом такої зустрічі $є$ формування $\mathrm{i}$ розвиток інтенціонального та ціннісного компонентів підприємницької культури здобувачів вищої освіти.

Запропонованою програмою в межах теми «Маркетингові стратегії» передбачено проведення індивідуального заняття (2 год.), метою якого $\epsilon$ допомога студентам у вирішенні питання щодо планування підприємницької діяльності. При цьому використовується метод евристичної бесіди. Учасниками заняття виступають студенти, які виявили значну зацікавленість у підприємницькій кар'єрі.

Обговорення. У затвердженому МОН України Стандарті вищої освіти спеціальності 017 «Фізична культура i спорт» (ступінь бакалавр) серед спеціальних (фахових, предметних) компетентностей здобувачів освіти зазначено «здатність застосовувати сучасні технології управління суб'єктами сфери фізичної культури i спорту», а серед результатів навчання «аргументувати управлінські рішення для вирішення проблем, які виникають в роботі суб'єктів фізичної культури і спорту...» (Standart vyshchoi osvity Ukrainy, 2019). Слід зазначити, що до сучасних технологій управління об'єктами сфери фізичної культури і спорту належать як управлінські, так і маркетингові технології, а також інформаційно-технічні технології.

Однак аналіз освітньо-професійних програм (ОПП) деяких вітчизнаних 3ВО показав, що дисципліни, вивчення яких сприяє формуванню зазначеної компетенності, або зовсім відсутні у переліку компонент ОПП (Osvitnjoprofesijna proghrama «Fizychna kultura i sport. Trenerska diialnist z vydu sportu pershoho rivnia vyshchoi osvity za spetsialnistiu 017 Fizychna kultura i sport, Berdianskyi derzhavnyi pedahohichnyi universytet, 2019), або представлені дисциплінами «Управління фізичною культурою і спортом» (Osvitno-profesiina prohrama «Fizychna kultura i sport» pershoho (bakalavrskoho) rivnia vyshchoi osvity, Khersonskyi derzhavnyi universytet, 2019), «Управління та менеджмент у сфері фізичної культури і спорту» (Osvitno-profesiina prohrama pidhotovky bakalavra pershoho rivnia vyshchoi osvity za spetsialnistiu 017 Fizychna kultura i sport, Mykolaivskyi natsionalnyi universytet imeni V.O. Sukhomlynskoho, 2017), «Економіка» (Osvitno-profesiina prohrama «Fizychna kultura i sport» pershoho (bakalavrskoho) rivnia vyshchoi osvity, Ternopilskyi natsionalnyi pedahohichnyi universytet imeni Volodymyra Hnatiuka, 2019), «Менеджмент рекреаційнооздоровчої роботи та організація і методика масової фізичної культури» (Osvitno-profesiina prohrama «Trenerska diialnist v obranomu vydi sportu» pershoho rivnia vyshchoi osvity za spetsialnistiu 017 Fizychna kultura i sport, Kharkivska derzhavna akademiia fizychnoi kultury, 2017).

Дисципліни, завданням яких $є$ формування у здобувачів вищої освіти маркетингових компетенцій, здебільшого включені до навчальних планів магістерських програм. Однак вважаємо, що відповідні знання i навички необхідні також і виспускникам бакалаврату для того, щоб розширити їхні 
можливості щодо працевлаштування. Отже, підвищення якості вищої освіти на першому (бакалаврському) рівні потребує розроблення й включення до змісту ОПП дисципліни «Маркетинг фізичної культури і спорту».

Висновки. Наведена у статті логіка проведення аудиторної i забезпечення виконання самостійної роботи студентів під час вивчення дисципліни «Маркетинг фізичної культури і спорту» створює умови для формування: навичок визначення й задоволення потреб та інтересів споживачів; навичок здійснення аналізу ринку послуг професійних тренерів, агентів, менеджерів та інших фахівців; вміння встановлювати конкурентоспроможну ціну на спортивно-оздоровчі послуги; розуміння сутності створення й просування власного бренду; здатності обирати й проводити найбільш ефективні PR-заходи; навичок аналізу зовнішніх загроз і можливостей, а також внутрішніх сильних і слабких сторін власного бізнесу; навичок розроблення маркетингового плану для власного стартапу; упевненості студентів у власному підприємницькому потенціалі.

Перспективами подальших розвідок у зазначеному напрямі може бути розроблення логіки викладання та змісту навчальної дисципліни «Підприємництво у фізичній культурі і спорті».

\section{ЛITЕРАТУРА:}

Blank S. (2009). Building a Company with Customer Data - Why Metrics Are Not Enough. Retrieved from: https://steveblank.com/category/marketing/ page/2/.

Blank S. (2017). Don't let process distract you from finding the strategy. Retrieved from: https://steveblank.com/category/customer-development/ page/3/.

Blank S. (2020). Rising out of the Crisis: Where to Find New Markets and Customers. Retrieved from: https://steveblank.com/category/customer-development/.

Кількість зареєстрованих безробітних та кількість вакансій у 2019 році (за даними державної служби зайнятості). URL: http://www.ukrstat. gov.ua/.

Освітньо-професійна програма «Тренерська діяльність в обраному виді спорту» першого рівня вищої освіти за спеціальністю 017 Фізична культура і спорт. Х.: Харківська державна академія фізичної культури, 2017. 12 c. URL: https://khdafk.kh.ua/wpcontent/uploads/ 2019/04/017-Фізична-культура-і-спорт-1.pdf.

Освітньо-професійна програма «Фізична культура і спорт. Тренерська діяльність з виду спорту» першого рівня вищої освіти за спеціальністю 017 Фізична культура і спорт. Бердянськ: Бердянський державний педагогічний університет, 2019. 16 с. URL: http://bdpu.org/wp-content/uploads/2020/03/017_FKS_Sport-1.pdf.

Освітнь--професійна програма «Фізична культура і спорт» першого (бакалаврського) рівня вищої освіти. Херсон: Херсонський державний університет, 2019. 22 с. URL: http://www.kspu.edu/

FileDownload.ashx/ОПП\%20017\%20ФІЗИЧНА\%20КУЛЬТУРА\%20

I\%20СПОРТ\%20БАКАЛАВР\%20(1).pdf?id=8e8ede49-e4aa-4104-956d-7538f5830f66.

Освітньо-професійна програма «Фізична культура і спорт» першого (бакалаврського) рівня вищої освіти. Тернопіль: Тернопільський національний педагогічний університет імені Володимира Гнатюка, 2019. 19 с. URL: http://tnpu.edu.ua/about/public_inform/akredytatsiia\%

20ta\%20litsenzuvannia/osvitni_prohramy/bakalavr/fizvyh/017_Fizychna_kultura_i_sport_b akalavr_2019.pdf. 
Освітньо-професійна програма підготовки бакалавра першого рівня вищої освіти за спеціальністю 017 Фізична культура і спорт. Миколаїв: Миколаївський національний університет імені В.O. Сухомлинського, 2017. 14 c. URL: http://sport.mdu.edu.ua/fks/ wp-content/uploads/2017/OПП_017_ФКiC.pdf.

Потапюк І. П. Особливості застосування комплексу маркетингу на підприємствах сфери фізичної культури і спорту. Економічний часопис-XXI. 2011. №11-12. URL: http://soskin.info/ea/2011/11-12/201122.html.

Разумовський С. О. Маркетинг фізичної культури як елемент соціальної сфери суспільства (соціально-філософський аналіз). Слобожанський науково-спортивний вісник. 2013. № 2. C. 199-203.

Самодай В. Актуальні питання щодо впровадження маркетингу у сферу фізичної культури $\mathrm{i}$ спорту. Молода спортивна наука Украӥни. 2013. Т. 4. С. 158-165.

Стандарт вищої освіти України. Ступінь вищої освіти бакалавр. Галузь знань 01 освіта/педагогіка. Спеціальність 017 Фізична культура і спорт. Київ: Міністерство освіти і науки України, 2019. 12 с. URL: https://mon.gov.ua/storage/app/media/vishchaosvita/zatverdzeni\%20standarty/2019/04/25/017-fizichna-kultura-i-sport-bakalavr.pdf.

Танклевська Н. С., Вибранський В. В. Основи маркетингу в спортивній сфері. Соціальноекономічні проблеми сучасного періоду України. 2019. Вип. 6 (140). С. 20-25.

Тищенко Т. Б. Особливості формування готовності майбутніх фахівців фізичного виховання та спорту до маркетингової діяльності. Науковий часопис [Національного педагогічного університету імені М. П. Драгоманова]. Серія 15: Науковопедагогічні проблеми фізичної культури (фізична культура і спорт): зб. наук. пр. 2010. № 3. С. 307-310.

\section{REFERENCES:}

Blank, S. (2009). Building a Company with Customer Data - Why Metrics Are Not Enough. Retrieved from: https://steveblank.com/category/marketing/ page/2/.

Blank, S. (2017). Don't let process distract you from finding the strategy. Retrieved from: https://steveblank.com/category/customer-development/ page/3/.

Blank, S. (2020). Rising out of the Crisis: Where to Find New Markets and Customers. Retrieved from: https://steveblank.com/category/customer-development/.

Kilkist zareiestrovanykh bezrobitnykh ta kilkist vakansii u 2019 rotsi (za danymy derzhavnoi sluzhby zainiatosti). (2019). [The number of registered unemployed and the number of vacancies in 2019 (according to the state employment service)]. URL: http://www.ukrstat.gov.ua/. (in Ukrainian).

Osvitno-profesiina prohrama «Fizychna kultura i sport. Trenerska diialnist z vydu sportu pershoho rivnia vyshchoi osvity za spetsialnistiu 017 Fizychna kultura i sport. (2019). [Educational and professional program "Physical Culture and Sports. Coaching activities in the sport of the first level of higher education in the specialty 017 Physical culture and sports]. Berdiansk: Berdianskyi derzhavnyi pedahohichnyi universytet. 16 p. URL: http://bdpu.org/wp-content/uploads/2020/03/017_FKS_Sport-1.pdf. (in Ukrainian).

Osvitno-profesiina prohrama «Fizychna kultura i sport» pershoho (bakalavrskoho) rivnia vyshchoi osvity. (2019). [Educational and professional program "Physical Culture and Sports" of the first (bachelor's) level of higher education]. Kherson: Khersonskyi derzhavnyi universytet. 22 p. URL: http://www.kspu.edu/FileDownload.ashx/OPP\% 20017\%20FIZYChNA\%20KULJTURA\%20I\%20SPORT\%20

BAKALAVR\%20(1).pdf?id=8e8ede49-e4aa-4104-956d-7538f5830f66. (in Ukrainian).

Osvitno-profesiina prohrama «Fizychna kultura i sport» pershoho (bakalavrskoho) rivnia vyshchoi osvity. (2019). [Educational and professional program "Physical Culture and Sports" of the first (bachelor's) level of higher education]. Ternopil: Ternopilskyi natsionalnyi 
pedahohichnyi universytet imeni Volodymyra Hnatiuka. 19 p. URL: http://tnpu.edu.ua/about/public_inform/akredytatsiia\%20 ta\%20litsenzuvannia/osvitni_prohramy/bakalavr/fizvyh/017_Fizychna_kultura_i_sport_bak alavr_2019.pdf. (in Ukrainian).

Osvitno-profesiina prohrama «Trenerska diialnist v obranomu vydi sportu» pershoho rivnia vyshchoi osvity za spetsialnistiu 017 Fizychna kultura i sport. (2017). [Educational and professional program "Coaching in the chosen sport" of the first level of higher education in the specialty 017 Physical Culture and Sports]. Kharkiv: Kharkivska derzhavna akademiia fizychnoi kultury. 12 p. URL: https://khdafk.kh.ua/wp-content/uploads/ 2019/04/017Fizychna-kuljtura-i-sport-1.pdf. (in Ukrainian).

Osvitno-profesiina prohrama pidhotovky bakalavra pershoho rivnia vyshchoi osvity za spetsialnistiu 017 Fizychna kultura i sport. (2017). [Educational and professional bachelor's program of the first level of higher education in the specialty 017 Physical culture and sports]. Mykolaiv: Mykolaivskyi natsionalnyi universytet imeni V. O. Sukhomlynskoho. 14 p. URL: http://sport.mdu.edu.ua/fks/wp-content/uploads/2017/OPP_017_FKiS.pdf. (in Ukrainian).

Potapiuk, I. P. (2011). Osoblyvosti zastosuvannia kompleksu marketynhu na pidpryiemstvakh sfery fizychnoi kultury i sportu. [Features of application of a marketing complex at the enterprises of sphere of physical culture and sports]. Ekonomichnyj chasopys-XXI - Economic JournalXXI. № 11-12. URL: http://soskin.info/ea/2011/11-12/201122.html. (in Ukrainian).

Razumovskyi, S. O. (2013). Marketynh fizychnoi kultury yak element sotsialnoi sfery suspilstva (sotsialno-filosofskyi analiz). [Marketing of physical culture as an element of the social sphere of society (socio-philosophical analysis)]. Slobozhanskyi naukovo-sportyvnyi visnykSlobozhansky scientific and sports bulletin. № 2. P. 199-203. (in Ukrainian).

Samodai, V. (2013). Aktualni pytannia shchodo vprovadzhennia marketynhu u sferu fizychnoi kultury i sportu. [Current issues regarding the introduction of marketing in the field of physical culture and sports]. Moloda sportyvna nauka Ukrainy - Young sports science of Ukraine. T. 4. P. 158-165. (in Ukrainian).

Standart vyshchoi osvity Ukrainy. Stupin vyshchoi osvity bakalavr. Haluz znan 01 osvita/pedahohika. Specialnist 017 Fizychna kultura i sport. (2019). [Standard of higher education in Ukraine. Bachelor's degree. Field of knowledge 01 education / pedagogy. Specialty 017 Physical culture and sports]. Kyiv: Ministerstvo osvity i nauky Ukrainy. 12 p. URL: https://mon.gov.ua/storage/app/media/vishcha-osvita/zatverdzeni\%20standarty/2019/ 04/25/017-fizichna-kultura-i-sport-bakalavr.pdf. (in Ukrainian).

Tanklevska, N. S. \& Vybranskyi, V. V. (2019). Osnovy marketynhu v sportyvnii sferi. [Fundamentals of marketing in sports]. Socialno-ekonomichni problemy suchasnoho periodu Ukrainy - Socio-economic problems of the modern period of Ukraine. Vypusk 6 (140). P. 20-25. (in Ukrainian).

Tyshchenko, T. B. (2010). Osoblyvosti formuvannia hotovnosti maibutnikh fakhivtsiv fizychnoho vykhovannia ta sportu do marketynhovoi diialnosti. [Features of formation of readiness of future specialists of physical education and sports for marketing activity]. Naukovyi chasopys [Natsionalnoho pedahohichnoho universytetu imeni M. P. Drahomanova]. Seriia 15: Naukovo-pedahohichni problemy fizychnoi kultury (fizychna kultura i sport): zb. nauk. pr. - Scientific journal [National Pedagogical University named after MP Drahomanov]. Series 15: Scientific and pedagogical problems of physical culture (physical culture and sports). № 3. P. 307-310. (in Ukrainian).

\section{Інформація про автора: \\ Верітов Олександр Ігорович}

ORCID ID: http://orcid.org/0000-0002-3793-
Information about the author: Veritov Oleksandr Igorovych

ORCID ID: http://orcid.org/0000-0002-3793- 
3010, кандидат наук з фізичного виховання i спорту, старший викладач кафедри фізичної культури і спорту, Запорізький національний університет, 69600, м. Запоріжжя, вул. Жуковського, 66

e-mail: ffeftb@gmail.com
3010, PhD (Physical Education and Sports),

Senior lecturer at the Department of Physical Culture and Sports, Zaporizhia National University, 69600, Zaporizhia, Zhukovskoho st., 66 e-mail: ffeftb@gmail.com

Цитуйте цю статтю як: Верітов О.І. Формування маркетингових компетенцій бакалаврів із фізичної культури і спорту. Теорія та методика навчання та виховання. 2020. № 49. С.2942.

DOI: https://doi.org/10.34142/23128046.2020.49.03

Дата надходження статті до редакції: 20.11.2020 р.

Стаття прийнята до друку: 02.12.2020 р. 